\title{
Autumn and spring drought periods affect vegetation on high elevation rangelands of Turkey
}

\author{
Ali KOÇ \\ Author is associate professor, Department of Agronomy, Faculty of Agriculture, Atatürk University, 25240 Erzurum, Turkey.
}

\begin{abstract}
The amount and temporal distribution of precipitation received is of critical importance for regrowth and plant production on rangelands. The effects of drought in the autumn, and spring/summer, as they affected sheep fescue (Festucaa ovina L.) dominated vegetation in Eastern Anatolia, Turkey, were examined between 1996 and 1998. Artificial drought was created using polyethylene rain-out shelters. The experiment was a randomized complete block design with 3 replications with a split-plot arrangement of treatments. Main plots included 2 autumn treatments: imposed artificial autumn-drought or a $40 \mathrm{~mm}$ of additional water plus rain. Sub-plots contained 4 treatments: artificial drought in May, June, July, or full spring rainfall. The number of reproductive shoots, aboveground biomass production, protein content, protein yield, canopy coverage and botanical composition were determined. Reproductive shoot numbers were reduced from 617 to $31 \mathrm{~m}^{-2}$ when plants entered winter without autumn regrowth as a result of autumn-drought. Plots subjected to drought in the autumn had aboveground biomass of $424 \mathrm{~kg} \mathrm{ha}^{-1}$. Protein content of forage, crude protein yield and water use efficiency (WUE) were $11.6 \%, 49 \mathrm{~kg} \mathrm{ha}^{-1}$ and 1.5 , respectively. These were compared with $1,038 \mathrm{~kg} \mathrm{ha}^{-1}, 9.6 \%, 99 \mathrm{~kg} \mathrm{ha}^{-1}$, and 2.4 , respectively, for plots received normal autumn precipitation in addition to $40 \mathrm{~mm}$ of additional water. Aboveground biomass production increased as short-term drought in spring was delayed but WUE was decreased. Autumn-drought had no effect on the proportion of grasses, but reduced legumes and resulted in an increase in other species. Spring/summer-drought had no effect on legumes but, as the onset of drought was delayed, grasses decreased and other species increased in composition. Autumn-drought reduced canopy coverage from $34.7 \%$ to $23.8 \%$ but spring drought had a negligible effect. Results indicated that autumn precipitation was crucial for productivity of these high elevation rangelands.
\end{abstract}

Key Words: Festuca ovina, water use efficiency (WUE), biomass, botanical composition, protein

The author wishes to thank Dr. Faik Kantar for his critical reading and valuable comments on the manuscript, and Dr. Ahmet Gokkus for his help during the study.

Research was funded by the Faculty of Agriculture, Atatürk University, Grant No. TAB 96-2/127.
Resumen

La cantidad y distribución temporal de la precipitación recibida es de importancia crítica para el rebrote y la producción de las plantas de los pastizales. Entre 1996 y 1998, al este de Anatolia, Turquía, se examino como la sequía en otoño y primavera/verano afectan la vegetación dominada por "Sheep fescue" (Festucaa ovina L.). Se creó una sequía artificial utilizando protectores contra lluvia hechos con polietileno. El experimento se condujo en un diseño de bloques completos al azar en parcelas divididas con tres repeticiones. Las parcelas principales incluyeron 2 tratamientos de otoño: 1. sequía de otoño impuesta artificialmente y $2.40 \mathrm{~mm}$ de agua adicional mas lluvia. Las subparcelas contenían 4 tratamientos: sequía artificial en Mayo, Junio, Julio y la precipitación total de primavera. Se determinó el número de ramas reproductivos, la producción de biomasa aérea, el contenido y rendimiento de proteína, la cubertura de la copa y la composición botánica. Cuando las plantas llegaron al invierno sin rebrote de otoño como resultado de la sequía de otoño, el número de tallos reproductivos se redujo de 617 a $31 \mathrm{~m}^{-1}$. Las parcelas sujetas a sequía en otoño tuvieron una biomasa aérea de $424 \mathrm{~kg} \mathrm{ha}^{-1}$. El contenido de proteína del forraje, el rendimiento de proteína cruda y la eficiencia del uso del agua (EUA) fueron: $11.6 \%, 49 \mathrm{~kg} \mathrm{ha}^{-1}$ and 1.5, respectivamente. Estos valores se compararon con los de parcelas que recibieron la precipitación normal de otoño mas $\mathbf{4 0} \mathbf{~ m m}$ de agua adicionales y que fueron: $1,038 \mathrm{~kg} \mathrm{ha}^{-1}, 9.6 \%, 99 \mathrm{~kg} \mathrm{ha}^{-1}$, and 2.4 , respectivamente. La producción de biomasa aérea aumento conforme se retrasó la sequía de periodo corto de primavera, pero la EUA disminuyó. La sequía de otoño no tuvo efecto en la proporción de zacates, pero redujo las leguminosas y resulto en un incremento de otras especies. La sequía de primavera/verano no tuvo efecto en las leguminosas, pero conforme se retrasó el final de la sequía, los zacates disminuyeron y otras especies incrementaron su composición. La sequía de otoño redujo la cobertura de la copa de $34.7 \%$ a $23 . \%$ y la sequía de primavera no tuvo efecto significativo. Los resultados indican que la precipitación de otoño fue crucial para la productividad de estos pastizales de alta elevación.

Most of 21 million ha rangelands of Turkey, occupying $28 \%$ of the total land area, occur in arid and semiarid areas. These rangelands are usually situated in the regions with elevations above $1,000 \mathrm{~m}$ and cool season plants such as sheep fescue (Festuca ovina L.) are dominant (Serin and Tan 1998). A paucity of precipitation restricts plant growth in these areas and forage production varies with fluctuations in climatic conditions (Herbel and Pieper 1991). The amount and temporal distribution of precipita- 
tion are the most important factors that affect water use efficiacy (WUE) and forage production (Le Houerou 1984). Precipitation received in the preceding autumn is critical for forage production (Walker et al. 1994), since cool season grasses require vernalization or short days for reproductive shoot development in arid areas where summer dormancy occurs (McDonald et al. 1996).

Drought not only reduces plant biomass and forage quality, but also alters species composition of rangeland vegetation. Under drought conditions, protein content of forage may increase as a result of a reduction in the fraction of stems to leaves produced (Peterson et al. 1992). Depending on the severity of drought, botanical composition may change and canopy coverage may also be reduced (Olson et al. 1985, Snyman and van Rensburg 1990, Snyman and Fouche 1993, Moldenhauer 1998).

Eastern Anatolia is the highest elevation (average $1,400 \mathrm{~m}$ ) region in Turkey and more than half of its total area is rangelands (52.4\%), making animal husbandry an important activity in the region (Gokkus and Koc 1996a). Eastern Anatolia's climate is semiarid with large fluctuations in precipitation within and between years. No work has been done on the effects of drought on biomass production in rangelands in Turkey. This study was undertaken to investigate the effects of drought during different periods (autumn or growing season) on the aboveground biomass, forage quality, botanical composition, canopy cover and WUE of vegetation.

\section{Materials and Methods}

This study was conducted on natural rangelands of Atatürk University, Erzurum, Turkey $\left(39^{\circ} 55^{\prime} \mathrm{N}, 41^{\circ} 61^{\prime} \mathrm{E}\right.$ with an elevation of $1853 \mathrm{~m}$ ) between September 1996 and July 1998. The soil was sandy-loam with a neutral $\mathrm{pH}$, low lime but rich potassium content. The soil was poor in phosphorous content with an organic matter content of $2.7 \%$ (Anon. 1998). The long term average yearly precipitation is $450 \mathrm{~mm}$ and the average annual temperature is $6^{\circ} \mathrm{C}$. Precipitation during the experimental period is compared with long term average monthly precipitation in Figure 1.

Rangeland plants began spring growth in the last week of April and entered summer dormancy about the end of July, with growth ceased by lack of soil moisture.

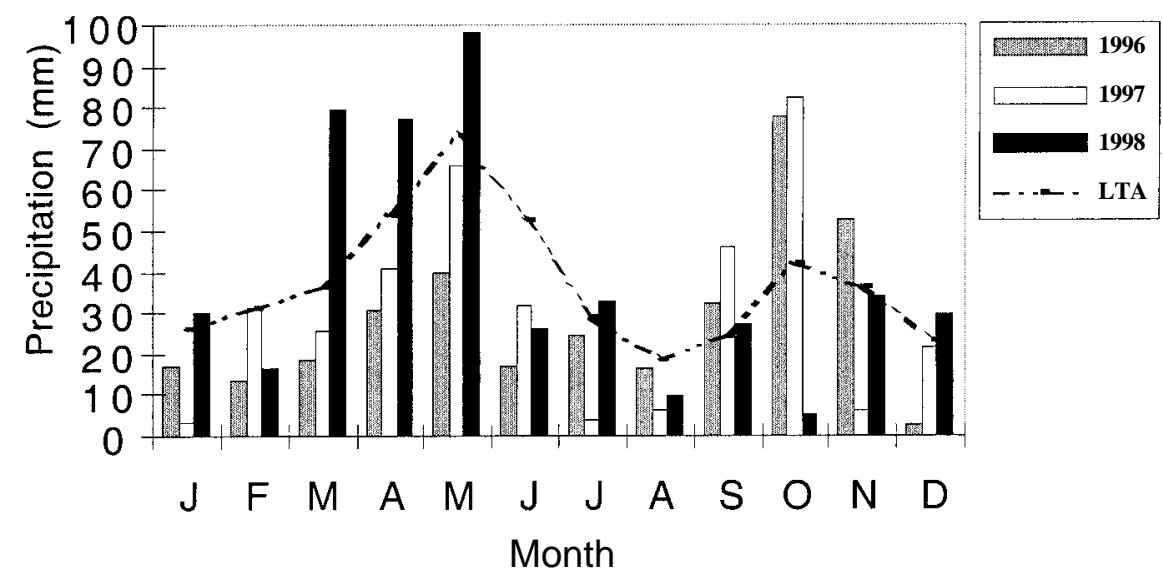

Fig. 1. Total monthly precipitation received during the experimental years and long term (1929-1998) average (LTA).

Plant regrowth occurs after the end of September when precipitation is received, or plants go directly into winter dormancy without shoot regrowth in the absence of precipitation (Koc 1995).

A randomized complete block design experiment with 3 replicates for 2 years was used in this study. A split-plot arrangement of treatments were used, with repeated measurement through 2 years. Main plots were 2 autumn treatments; artificial autumn-drought (a), and addition of $40 \mathrm{~mm}$ of supplemental water to support autumn regrowth (b). Autumn-drought main plots were covered with a clean polyethylene rain-out shelter which was open along each side to a height of $1 \mathrm{~m}$ above the ground to allow ventilation. These plots were covered between 15 September and 1 November to create artificial autumn-drought, while the other main plots received $40 \mathrm{~mm}$ of irrigation in addition to normal precipitation to enhance autumn growth. Supplemental water was applied once on 15 September in both years. Three of 4 sub-plots were sheltered from rain in either May (a), June (b) or July (c), and the other sub-plots received full spring rainfall $(\mathrm{d})$. The total

Table 1. The amount of water (precipitation + irrigation or rain out) received on sub-plot during the experiment.

\begin{tabular}{|c|c|c|c|c|c|}
\hline \multirow[b]{2}{*}{ Year } & \multicolumn{2}{|l|}{ Autumn } & \multicolumn{2}{|c|}{ Spring/summer treatment } & \multirow[b]{2}{*}{ Rain fed } \\
\hline & Treatment & May drought & June drought & July drought & \\
\hline & & ------------- & ----mm------- & 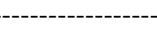 & \\
\hline \multirow[t]{2}{*}{1997} & Drought & 191 & 225 & 254 & 257 \\
\hline & Wet & 330 & 364 & 394 & 396 \\
\hline \multirow[t]{2}{*}{1998} & Drought & 263 & 335 & 355 & 361 \\
\hline & Wet & 430 & 502 & 522 & 528 \\
\hline
\end{tabular}

amount of water gained from precipitation and irrigation during the period between 15 September and 15 July in the experimental plots during the study years is presented in Table 1. Each sub-plot was 4-by$4 \mathrm{~m}$. A $1-\mathrm{m}$ buffer on each side was excluded from observation within each sub-plot.

When the dominant plant species, sheep fescue, was at the flowering stage, plant samples were taken by clipping two, $0.5 \mathrm{x}$ $0.5 \mathrm{~m}$ areas within each sub-plot to soil surface. After the reproductive shoots were counted, litter and dead material were separated. The live plant material was oven dried at $100^{\circ} \mathrm{C}$ for 20 hours (Anon. 1987) to determine aboveground biomass. Total $\mathrm{N}$ content was analyzed using the Micro Kjeldahl method and crude protein content calculated by multiplying $\mathrm{N}$ content by 6.25 (Anon. 1987). Water use efficiency (WUE) was estimated as aboveground biomass $\left(\mathrm{kg} \mathrm{ha}^{-1}\right)$ divided by total amount of water received an a sub-plot, including precipitation and irrigation, between 15 September and 15 July (Snyman and Fouche 1991).

Botanical composition and plant canopy coverage was determined each year using 
the line intercept method (5 transects within each sub-plots, each being $2 \mathrm{~m}$ long). After determining the ratio of plant species, plants were grouped as grasses, legumes and other species. The other species group consisted primarily of forbs. Total canopy coverage was calculated as the ratio of the total plant intercepts to the total length of the transect (Tosun 1968).

An arc-sine transformation was used data for botanical composition and plant canopy cover. All data were subjected to analysis of variance based on general linear models for repeated measurements for a split plot arrangement of treatments using the MSTATC statistical package (Nissen 1983). Means were separated using Least Significant Difference (LSD) Test.

\section{Results}

There was no fall regrowth in autumndrought plots, but grasses had 4-6 new leaves before the onset of the winter dormant period in autumn-wet plots in both years. An average of 617 reproductive shoots $\mathrm{m}^{-2}$ was produced when $40 \mathrm{~mm}$ of supplemental water was applied in the previous autumn. Only 31 tillers were produced when artificial autumn-drought was applied as compared with tillers when additional water was applied (Table 2). Spring/summer-drought timing had no significant effect on reproductive shoot number $(P>0.05)$. Shoot number was greater in the wetter year of 1998 than in 1997. No significant interaction effects among treatments occurred for reproductive shoot number.

Both autumn and spring/summerdrought significantly reduced aboveground biomass production $(\mathrm{P}<0.01)$. Autumn-drought reduced biomass production more than did spring/summer-drought (Table 2). The most severe reduction in production occurred if drought occurred in May. Thereafter, the effect of drought decreased as the onset of drought was delayed. Drought that occurred in July had no effect on production as compared with the rainfed treatment. Aboveground biomass was greater in wet year of 1998 than in 1997. There was no significant interaction among the treatments that affected aboveground biomass production.

Crude protein content was higher $(\mathrm{P}<$ $0.01)$ in the drier first year than in the secont year (Table 2). Crude protein content of the forage from the plots subjected to autumn-drought was higher $(\mathrm{P}<0.01)$ than in other plots. Although artificial spring/summer-drought effects on crude protein content were insignificant, when data from both years were combined, crude protein content was higher in plant samples subjected to drought in June and July in the first year. But in the second year, crude protein content was higher for plants from the artificial May-drought treatment (Fig. 2). This may explain the year $\mathrm{X}$ spring-drought interaction effect $(\mathrm{P}$ $<0.05)$.

The effect of drought that occurred at different growth stages on crude protein yield was consistent with that of aboveground biomass production (Table 2). The differences were also significant $(\mathrm{P}<$ 0.05 ) in crude protein yield between the years, with greater protein yield in the wetter year.

Water use efficiency (WUE) was lower for plants in plots subjected to autumndrought compared with plants for autumnwatered plots $(\mathrm{P}<0.01)$, and there was no difference between years $(P>0.05)$. In spring, WUE was greater $(\mathrm{P}<0.05)$ when May-drought was imposed than in other treatments. There was no significant interactions for WUE.

Grasses were affected more by spring/summer-drought and legumes were affected more by autumn-drought, while other species were affected by both autumn and spring/summer-drought (Table 3). Drought that occurred in May caused an increase in grasses ratio in the

Table 2. The effect of autumn- and spring-drought on reproductive shoot numbers, aboveground biomass, crude protein content, crude protein yield and WUE on high elevation rangeland vegetation in Turkey in 1997 and 1998.

\begin{tabular}{|c|c|c|c|c|c|c|c|}
\hline \multirow[b]{2}{*}{$\begin{array}{l}\text { Autumn } \\
\text { treatment }\end{array}$} & \multicolumn{3}{|c|}{ Spring/summer treatment } & \multicolumn{3}{|c|}{ Year } & \multirow[b]{2}{*}{1998} \\
\hline & $\begin{array}{c}\text { May } \\
\text { drought }\end{array}$ & $\begin{array}{l}\text { June } \\
\text { drought }\end{array}$ & $\begin{array}{c}\text { July } \\
\text { drought }\end{array}$ & $\begin{array}{c}\text { Rain } \\
\text { fed }\end{array}$ & Average & 1997 & \\
\hline & & & roductive s & (Shoot & ---------- & -------- & \\
\hline Drought & 28 & 28 & 29 & 40 & $31 b^{1}$ & 20 & 43 \\
\hline Wet & 585 & 608 & 629 & 644 & $617 \mathrm{a}$ & 550 & 684 \\
\hline Average & 307 & 318 & 329 & 342 & & $285 \mathrm{~b}$ & $363 \mathrm{a}$ \\
\hline Drought & 391 & 384 & 426 & $\begin{array}{c}\text { ion }(\mathrm{kg} \\
494\end{array}$ & $424 b$ & 340 & 508 \\
\hline Wet & 937 & 1039 & 1097 & 1079 & $1038 \mathrm{a}$ & 954 & 1122 \\
\hline Average & $664 c$ & $712 \mathrm{bc}$ & $762 \mathrm{ab}$ & $786 \mathrm{a}$ & & $647 \mathrm{~b}$ & $815 \mathrm{a}$ \\
\hline Drought & 11.5 & 11.6 & $\begin{array}{l}\text { Crude pro } \\
11.7\end{array}$ & $\begin{array}{l}\%)----- \\
11.6\end{array}$ & $11.6 \mathrm{a}$ & 12.0 & 11.2 \\
\hline Wet & 10.0 & 9.3 & 9.8 & 9.3 & $9.6 \mathrm{~b}$ & 10.3 & 8.9 \\
\hline Average & 10.7 & 10.4 & 10.8 & 10.4 & & $11.1 \mathrm{a}$ & $10.0 \mathrm{~b}$ \\
\hline Drought & 45 & 44 & $\begin{array}{l}\text { ude prot } \\
49\end{array}$ & $\begin{array}{c}\left.\text { ha }^{-1}\right)---- \\
56\end{array}$ & $49 \mathrm{~b}$ & ----- & 57 \\
\hline Wet & 93 & 96 & 107 & 100 & 99 a & 98 & 100 \\
\hline Average & $69 \mathrm{~b}$ & $70 \mathrm{~b}$ & $78 \mathrm{a}$ & $78 \mathrm{a}$ & & $69 \mathrm{~b}$ & $78 \mathrm{a}$ \\
\hline Drought & 1.7 & 1.3 & $\begin{array}{l}\text {-Water } \\
1.4\end{array}$ & 1.6 & $1.5 \mathrm{~b}$ & 1.5 & 1.5 \\
\hline Wet & 2.5 & 2.4 & 2.4 & 2.4 & $2.4 \mathrm{a}$ & 2.6 & 2.3 \\
\hline Average & $2.1 \mathrm{a}$ & $1.9 \mathrm{~b}$ & $1.9 \mathrm{~b}$ & $2.0 \mathrm{~b}$ & & 2.0 & 1.9 \\
\hline
\end{tabular}

${ }^{1}$ Means with the same letters within a row or column for each parameter are not significantly different $(\mathrm{P}>0.05)$. 


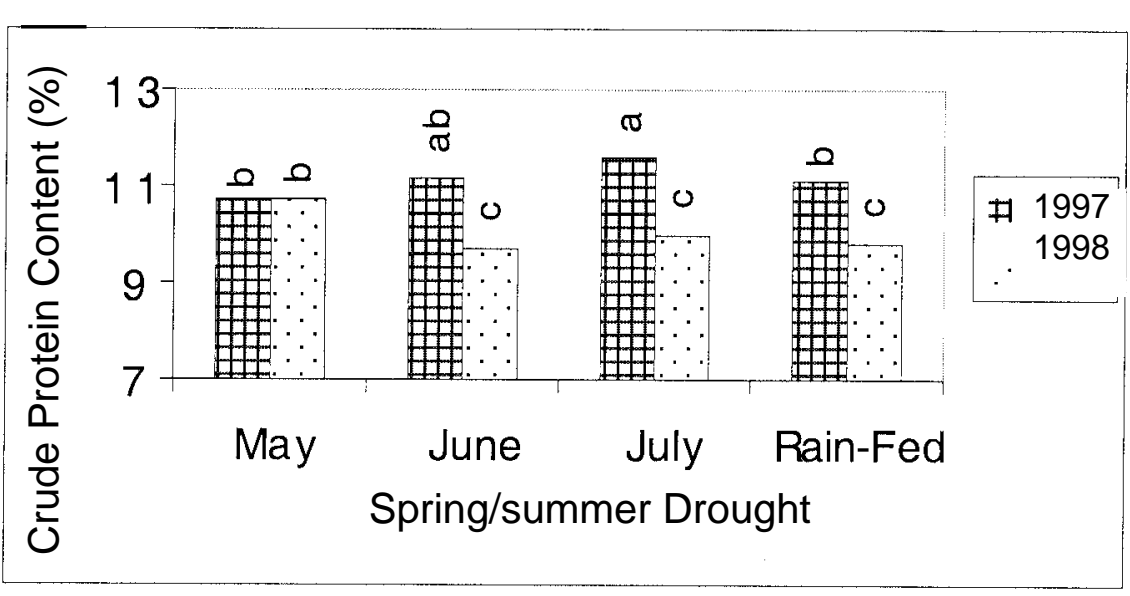

Fig. 2. Years $x$ spring drought interaction effects on crude protein content. The columns with the same letters are not statisstically different $(\mathrm{LSD}, \mathrm{P}<\mathbf{0 . 0 5})$.

botanical composition $(\mathrm{P}<0.01)$. The percentage of grasses was lower in the plots that were subjected to artificial drought in June with an autumn-drought as the main plots. However, grasses were lower in rain-fed sub plots of autumn-wet main plots, which resulted in significant $(\mathrm{P}<$ 0.05) interaction effects (Fig. 3). The percentage of legumes in the plots subjected to autumn-drought was $4.8 \%$, but increased significantly $(\mathrm{P}<0.05)$ to $9.6 \%$ when supplemental water was applied in autumn. Autumn-drought resulted in greater coverage of other plant species $(\mathrm{P}$ $<0.01)$. The coverage of these species increased from $16.3 \%$ to $23.4 \%$ as the drought was delayed in spring, but was similar between years. Interactions between autumn and spring/summer treatments were significant $(\mathrm{P}<0,05)$. This resulted from an increase in the fraction of other plant species in the rain-fed sub plots of autumn wet main plots compared with other treatments (Fig. 4).

Autumn-drought significantly reduced plant canopy coverage $(\mathrm{P}<0.01)$. Plant canopy coverage was $23.8 \%$ in the plots subjected to autumn-drought, but was $34.7 \%$ when supplemental water was applied in autumn. Spring/summerdrought periods had no effect on plant canopy coverage with no significant differences between years (Table 3 ). Interactions were also insignificant.

\section{Discussion}

Since rangeland ecosystems are located in arid and semiarid areas, precipitation is the most important factor that controls plant production in these ecosystems. Distribution of precipitation within a year is very important as is the total amount of precipitation. On high elevation rangelands, autumn precipitation had a great effect on plant production the following growing season in this study and in others (Walker et al. 1994). Plant production was related to the number of reproductive shoots produced in the preceding autumn. Reproductive shoot development in cool season grasses generally requires vernalization or short days (McDonald et al. 1996). Autumn moisture usually enhanced regrowth of reproductive shoots. Plants with low autumn reproductive shoot development produced vegetative shoots of varying height and sizes (Dahl 1995), which reduced total plant production and self regenerations of grasses. Our data showed that autumn drought resulted in considerable yield reductions.

Low aboveground biomass production when drought occurred in spring was related to lower leaf area, leaf number and shoot number, and depended on the intensity of stress (Busso and Richards 1995). As drought was delayed in the spring, reduction in aboveground biomass was associated with reductions in the effectiveness of precipitation, but depended on increases in ambient temperatures (Weltz and Blackburn 1995). Higher aboveground

Table 3. Effects of autumn- and spring-drought on plant composition and canopy coverage.

\begin{tabular}{|c|c|c|c|c|c|c|c|}
\hline \multirow[b]{2}{*}{$\begin{array}{l}\text { Autumn } \\
\text { treatment }\end{array}$} & \multicolumn{4}{|c|}{ Spring/summer treatment } & \multirow[b]{2}{*}{$\begin{array}{c}\text { Average } \\
\text { fed }\end{array}$} & \multicolumn{2}{|c|}{ Year } \\
\hline & May & $\begin{array}{c}\text { June } \\
\text { drought }\end{array}$ & $\begin{array}{c}\text { July } \\
\text { drought }\end{array}$ & $\begin{array}{c}\text { Rain } \\
\text { drought }\end{array}$ & & 1997 & 1998 \\
\hline & '--------- & $1 \sim$ & & asses $(\%)$ & & & ---- \\
\hline Drought & 73.7 & 65.0 & 71.9 & 72.7 & 70.8 & 73.9 & 67.7 \\
\hline Wet & 80.8 & 76.5 & 75.6 & 67.1 & 75.0 & 75.5 & 74.5 \\
\hline Average & $77.2 \mathrm{a}^{1}$ & $71.7 \mathrm{~b}$ & $73.8 \mathrm{ab}$ & $69.9 \mathrm{~b}$ & & 75.1 & 71.1 \\
\hline Drought & 3.2 & 6.8 & 5.3 & 3.7 & $4.8 \mathrm{~b}$ & 5.8 & 3.8 \\
\hline Wet & 9.8 & 9.2 & 9.9 & 9.5 & $9.6 \mathrm{a}$ & 8.8 & 10.4 \\
\hline Average & 6.5 & 8.0 & 7.6 & 6.6 & & 7.3 & 7.1 \\
\hline Drought & 23.1 & 28.2 & 22.8 & 23.6 & $24.4 \mathrm{a}$ & 20.3 & 28.5 \\
\hline Wet 9.4 & 14.3 & 14.4 & 23.4 & $15.4 \mathrm{~b}$ & 15.7 & 15.0 & \\
\hline Average & $16.3 \mathrm{c}$ & $21.3 \mathrm{ab}$ & $18.6 \mathrm{bc}$ & $23.5 \mathrm{a}$ & & 18.0 & 21.8 \\
\hline Drought & 23.4 & 23.2 & 25.4 & 23.4 & $23.8 \mathrm{~b}$ & 24.0 & 23.7 \\
\hline Wet & 34.2 & 34.6 & 35.5 & 34.6 & $34.7 \mathrm{a}$ & 34.7 & 34.8 \\
\hline Average & 28.8 & 28.9 & 30.5 & 29.0 & & 29.3 & 29.2 \\
\hline
\end{tabular}

${ }^{1}$ Means with the same letters within a row or column for each parameter are not significantly different $(\mathrm{P}>0.05)$. 


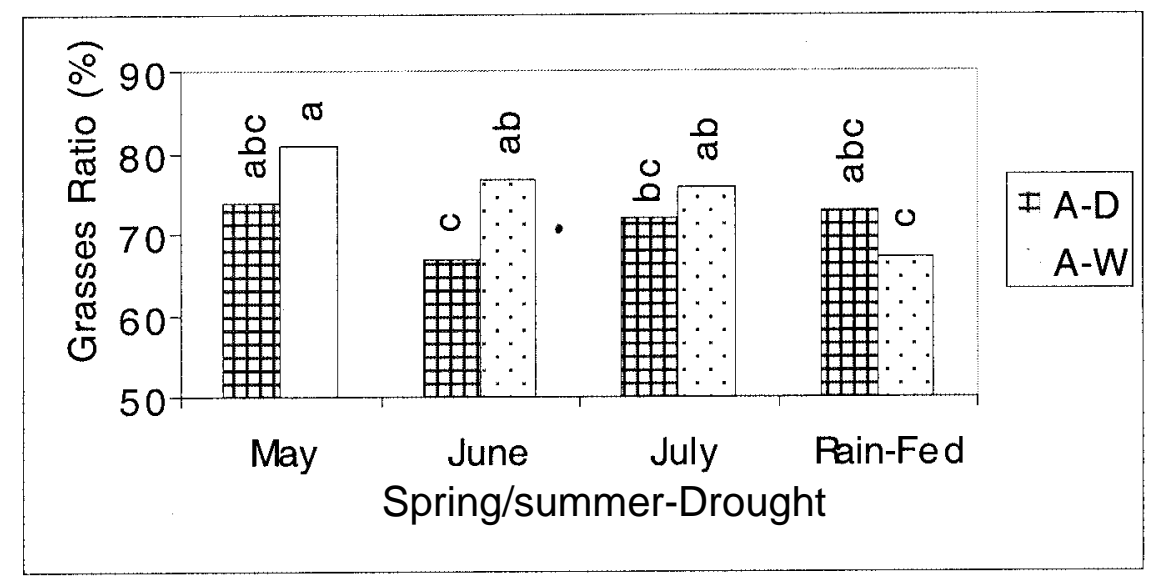

Fig. 3. Grasses ratio as affected by the interaction of autumn water regime and short growing season drought periods (A-D: autumn drought, A-W: autumn wet). The columns with the same letters are not statistically different (LSD, P $<0.05)$

biomass production in the second year was related to higher precipitation received compared to that received in the first year (Table 1).

Autumn-drought caused an increase in crude protein content of forage that resulted from reduced reproductive shoot development. A higher fraction of stems reduces crude protein content (Gokkus and Koc 1996b). Higher crude protein content in the first year was related to lower precipitation received in that year and less stem growth. Drought retarded growth, but enhanced crude protein content (Peterson et al. 1992). Trends in crude protein yield paralleled those of aboveground biomass production. Higher crude protein yield of forage produced when drought occurred in the autumn did not, however, alleviate the loss in total protein yield (Table 2).

Water use efficiency (WUE) decreased in response to increasing intensity of drought (Le Houerou 1984, Snyman and van Rensburg 1990; Snyman and Fouche 1991). Relatively lower WUE was recorded for plants in plots subjected to drought in the autumn as compared with those where spring occurred. This probably originated from the failure of grasses to form reproductive shoots of high dry matter production potential. Higher ratios of vegetative shoots may lead to lower amounts of dry matter produced per unit of water lost. Therefore, autumn-drought may reduce WUE of rangeland vegetation.

Drought in the spring/summer, especially in May, was most important in reducing aboveground biomass production, but WUE was the highest in these treatments. Precipitation is normally high in May in the region (Fig. 1), which indicates higher rates of daily dry matter accumulation (Koc and Gokkus 1996). Lack of water during this early growth period caused a heavy yield penalty (Table 2). However,

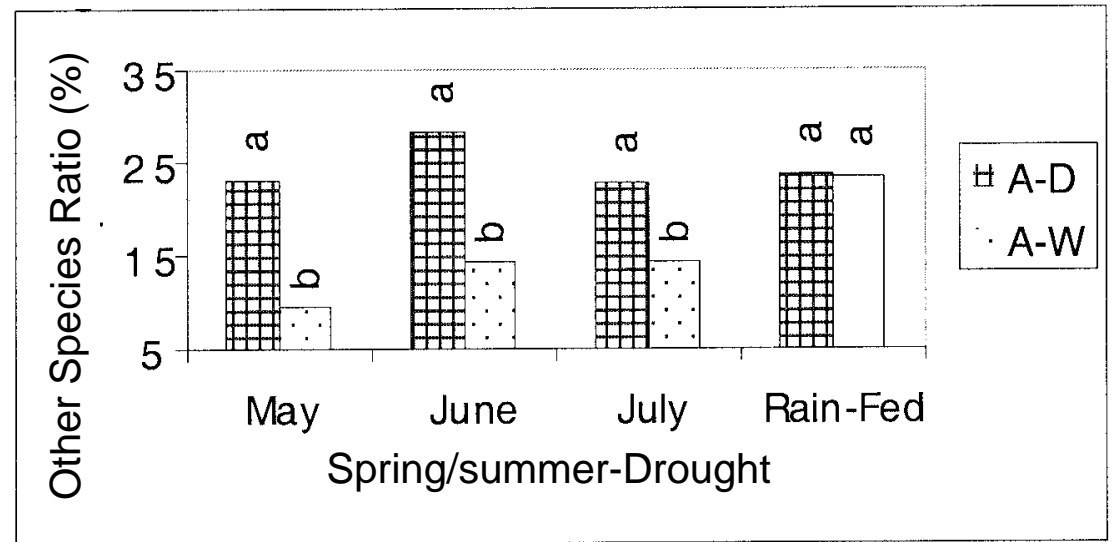

Fig. 4. Changes in the fraction of other species in relation to interaction of drought application period. The columns with the same letters are not statistically different (LSD, P < 0.05). the soil water supply that accumulated over the winter was effectively used (Weltz and Blackburn 1995), resulting in higher rates of WUE. In other drought treatments in spring/summer, WUE was low despite higher aboveground biomass production. This might be associated with rapid evaporation of the precipitation received during June and July.

Drought that occurred in autumn probably led to a reduction in the amount of water stored in lower layers of soil. This could explain the lower proportion of legumes in the vegetation, because legumes are more sensitive to drought stress than are grasses (Haynes 1980).

Drought that occurred after May increased the proportion of plant species that belonged to other families. These species are often unpalatable (invader) plants. Another study also reported that invader species increased depending on drought conditions (Snyman and van Rensburg 1990). The decrease in the ratio of other species in the May drought period might be attributed to the failure of germination of annual weed seeds because of low soil moisture.

Autumn-drought reduced production of reproductive shoots of grasses and consequently canopy coverage was less as a result of lower basal diameter. This was consistent with observations by other workers (Snyman and van Rensburg 1990, Snyman and Fouche 1991, Walker et al. 1994, Koc 1995).

In conclusion, sufficient precipitation in autumn was the most important factor for fall regrowth that affected plant production the following year in high elevation rangelands. Drought that occurred in autumn severely affected aboveground production in these rangelands. Therefore, sufficient autumn precipitation is of vital importance for plant production. In these high elevation rangelands, drought after May was of little consequence for plant production. Precipitation received between September and May was, therefore, of critical importance.

\section{Literature Cited}

Anonymous. 1987. Forage laboratory methods for feed analysis. ICARDA Bull. 125. Aleppo, Syria.

Anonymous. 1998. Soil analysis laboratory report of Department of Soil Science, Ataturk University, Erzurum, Turkey.

Busso, C.A. and J.H. Richards. 1995. Drought and clipping effects on tiller demography and growth of two tussock grasses in Utah. J. Arid Environ. 29:239-251. 
Dahl, B.E. 1995. Developmental morphology of plants, p. 22-58. In: D.J. Bedunah and R.E. Sosebee (eds.) Wildland plants: Physiological ecology and developmental morphology. Soc. Range Manage., Denver, Colo.

Gokkus, A. and A. Koc. 1996a. Agricultural structure in Eastern Anatolia Region (In Turkish with English Summary). p. 22-31. Proc. $3^{\text {rd }}$ Nat. Meadow, Range. and Forage Crop Congress, 1996, Erzurum, Turkey.

Gokkus, A. and A. Koc. 1996b. Canopy and root development of crested wheatgrass in relation to the quality and time of nitrogen application. Turkish J. Agr. and Forest. 20:289-293.

Haynes, R.J. 1980. Competitive aspects of the grass-legume association. Adv. in Agron. 33: 227-261.

Herbel, C.H. and R.D. Pieper. 1991. Grazing management, p. 361-385. In: J. Skujin (ed.) Semiarid lands and deserts: soil resources and reclamation. Marcel Deccer Inc., NY.

Koc, A. 1995. The effects of topography and soil climate on some properties of rangeland vegetation. Ph.D. Thesis (In Turkish with English Summary), Atatürk Univ. Erzurum, Turkey.

Koc, A. and A. Gokkus. 1996. Annual variation of aboveground biomass, vegetation height and crude protein yield on the natura rangelands of Erzurum. Turkish J. Agr. and Forest. 20:305-308.
Le Houerou, H.N. 1984. Rain use efficiency: a unifying concept in arid-land ecology. J. Arid Environ. 7:213-247.

McDonald Jr, M.B., L.O. Copeland, A.D. Knapp, and D.F. Grabe. 1996. Seed development, germination and quality. In: L.E. Moser, D.R. Buxton and M.D. Casler (eds.) Cool-season forage grasses, p. 15-70. Amer. Soc. Agron., Agron. No: 34, Madison, Wis.

Moldenhauer, L. 1998. Drought, no fear! Rangelands 20:30-31.

Nissen, O. 1983. MSTAT-C A microcomputer program for the design, management, and Analysis of Agronomic Research Experiments. Michigan State University, Mich.

Olson, K.C., R.S. White, and B.W. Sindelar. 1985. Response of vegetation of the Northern Great Plains to precipitation amount and grazing intensity. J. Range Manage. 38:356-361.

Peterson, P.R., C.C. Sheaffer, and M.H. Hall. 1992. Drought effects on perennial legume yield and quality. Agron. J. 84:774-779.

Serin, Y. and M. Tan. 1998. Forage grasses (In Turkish). Atatürk Univ. Faculty Agr. Pub. No. 334. Erzurum, Turkey.

Snyman, H.A. and H.J. Fouche. 1991. Production and water-use efficiency of semiarid grasslands of South Africa as affected by veld condition and rainfall. Water SA. 17:263-268.
Snyman, H.A. and H.J. Fouche. 1993. Estimating seasonal herbage production of a semi-arid grassland based on veld condition, rainfall and evapotranspiration. Afr. J. Range For. Sci. 10:21-24.

Snyman, H.A. and W.L.J. van Rensburg. 1990. Short-term effect of severe drought on veld condition and water use efficiency of grassveld in the central Orange Free State (In Dutch with English summary). J. Grassl. Soc. South. Afr. 7:249-256.

Tosun, F. 1968. Sampling intensities of pasture vegetation studies by the line-transect method (In Turkish with English Summary). Atatürk Univ. Agr. Res. Inst. Bull. 27. Erzurum, Turkey.

Walker, M.D., P.J. Webber, E.H. Arnold, and D. Ebert-May. 1994. Effects of interannual climate variation on aboveground phytomass in alpine vegetation. Ecol. 75:393-408.

Weltz, M.A. and W.H. Blackburn. 1995. Water budget for South Texas rangelands. J. Range Manage. 48:45-52. 